\title{
The impact of Umrah service quality on customer satisfaction towards Umrah travel agents in Malaysia
}

\author{
Bestoon Othman ${ }^{a^{*}}$, Amran Harun ${ }^{\mathrm{b}}$, Wirya Rashid ${ }^{\mathrm{c}}$ and Raman Ali ${ }^{\mathrm{d}}$
}

${ }^{a}$ Technology Management and Business University Tun Hussain Onn Malaysia and Department of Business Administration, Koya Technical Institute, Erbil Polytechnic University, Malayisa

${ }^{b}$ Technology Management and Business Universiti Tun Hussain Onn Malaysia, Malaysia

${ }^{c}$ Faculty of Administrative and Financial sciences, University of Cihan 46001, Sulaimani/Kurdistan, Iraq

${ }^{d}$ Technical college of administration, Sulaimani Polytechnic University 46001, Sulaimani/Kurdistan, Iraq

\section{H R O N I C L E}

\begin{tabular}{l} 
Article history: \\
Received: January 152019 \\
Received in revised format: May \\
152019 \\
Accepted: June 14, 2019 \\
Available online: \\
June 15, 2019 \\
\hline Keywords: \\
Umrah travel \\
Service quality \\
Customer satisfaction \\
Malaysia
\end{tabular}

\section{A B S T R A C T}

\begin{abstract}
The purpose of this paper is to discover the perception of Umrah travel agents regarding the impact of service quality (SQ) on customer satisfaction (CS) in Malaysia. To perform and accomplish this task, the necessary data were collected through convenience sampling method based on self-administrated structure questionnaire. Out of 500 responses from the respondents, 384 samples were finally chosen and considered suitable for descriptive statistics analysis to fulfil the sole purpose of the paper. There were positive and significant relationship between the retail SQ dimensions and CS. Umrah travel industry contributes significantly on the Malaysian economic growth, and during the last decade the competition has increased dramatically. Therefore, this research study is intended to seek for solid empirical justification to consider SQ as a major and substantial factor in $\mathrm{CS}$ in Malaysian Umrah traveling industry.
\end{abstract}

\section{Introduction}

Service quality (SQ) is one of the key factors and result oriented strategies to satisfy customers and convince them to become loyal customers by delivering quality based products and services to reach their needs and desires. To overcome any uncertainties and win the competitions marathon within the industry; a nonstop and continual improvement in the quality of offered products and services is needed. According to Rajaratnam et al. (2014) in the industry of Umrah travel most of the agents deliver their customers with some common services but different service quality is the key factor in gaining competitive advantage. Due to the fact that there are many organizations offering Umrah travel services to offer their services, the customers have the opportunity to choose the agents with quality-based services with comparatively lesser prices. To succeed in the industry the Umrah travel agents need to improve their responsibilities along through offering better services (Hassan et al., 2016). While according to Othman et al., (2018) the services of Umrah traveling is many Muslim countries is managed by the governments their

\footnotetext{
* Corresponding author.

E-mail address: bestoon2011@yahoo.com (B. Othman)

C 2019 by the authors; licensee Growing Science, Canada doi: $10.5267 /$ j.msl.2019.6.014
} 
self and many of them have less competent human resources and budgets. Further with regret this may lead to customer's dissatisfaction. Maula (2016) argues that customer's satisfaction is achieved when the quality of services provided meets the customer's expectations. Thus according to Kant and Jaiswal (2017), service quality actually is a quality service where clients, users or customers perceived when measured against their expectations before receiving buying the service. So, the Malaysian Umrah travel agencies must pay attention to find a solution to increase the customer satisfaction and decrease the dispute cases or customers dissatisfaction. Travel agents acts as an intermediary between consumers (traveller's perspectives) and producers (such as airlines, hotels). The industry in Malaysia has seen some considerable alliances and mergers, but still some of the agencies are working independently and running their small businesses which gets most of the revenue from commission paid by producers. The customer or prospective travellers who deal with an agency often get effective and good personal service, the travellers can also benefit from the agents' expertise (Othman et al. 2019). Therefore, the intention of this paper is to discover the perception of Umrah travel agents regarding the impact of service quality (SQ) on customer satisfaction (CS) in Malaysia.

\section{Literature Review}

The role of the service quality in the Umrah travel service customers has widely been discussed in the literature so far. This part of the papers provides some up to date knowledge and information regarding SQ and CS the existing literature.

\subsection{Service Quality}

According to Kumar (2018) providing services is a nonstop process of interaction between service providers and the customers, these services consist of various intangible activities for the solutions of customers' problems, in exchange of either systems useful financial or physical resources. Maula (2016) argues that the key to gain competitive advantage is to offer premium service quality in the services industry. According to Muala (2016); Ngo and Nguyen, (2016) and Parasuraman et al. (1988), the customers level of satisfaction is totally dependent on their perception and opinion regarding service quality after experiencing it and on the trust of its provider. By offering customers with qualitative services firms revive the customers' perception regarding the quality of services.

Specifically, in the industry of Umrah travelling, if premium service quality is offered it sends a good signal to the customers in the performance evaluation of both the services and it is an important key in gaining competitive advantage. Further Umrah travel agents can easily get competitive advantage through building long term relationship with the customers and by providing premium quality services. According to Kant and Jaiswal (2017); Kumar (2018); Saghier and Nathan, (2013); the literature is full of evidences in the support of the fact that there is a substantial correlation between CS and SQ. Parasuraman et al. (1988) developed a scale named SERVQUAL which is the most famous scale to measure the SQ. It measures and classifies the service quality in five dimensions. SERVQUAL scale has been widely used to measure the SQ. SERVQUAL scale has been widely and constructively deployed in various and many private research studies (Parasuraman et al., 1991, 2002). According to Muhammad et al. (2011), Vanniarajan and Gurunathan (2009), Khan and Fasih (2014) and Mahfooz (2014) the scale is widely and positively discussed in various prominent published research studies and Ashdaq et al. (2015); Jain and Gupta (2004); Omar et al., (2015); Thongthip and Polyorat (2015) insure its reliability and validity. On the basis of criticism made on SERVQUAL scale, proper and well defined refinements were made (Parasuraman et al., 1991).

Following are its dimension.

\subsubsection{Tangibles}

Tangible things are all things possessing a physical existence or appearance while we can see and touch them. According to Ngo and Nguyen (2016) based on SQ, equipment, Information and Communications 
Technology (ICT), physical facilities and appearance (ambience, lighting, air-conditioning, seating arrangement); organizations services providing personnel are all tangibles things. Organizations arrange tangibles things randomly and integrate it to render services to its customers who after its usage access it.

\subsubsection{Reliability}

In this case, Ngo and Nguyen (2016) termed reliability as the ability of service provider to offer the committed products and services consistently and truthfully. Customers are satisfied in a case they are provided with trustable services which they can rely.

\subsubsection{Responsiveness}

According to Parasuraman et al. (1985), Responsiveness is the employee's readiness or willingness in providing the services to customers. It involves services timeliness. It also deals with understanding the customer's needs, wants and desires, the staff attention given to employees, the convenient operating hours, properly attending and solving the customers problems, ease and safety in their transaction Izogo \& Ogba, 2015).

\subsubsection{Assurance}

Employees' knowledge and courtesy is the key factor towards assurance when customers render the services, and employees ability to create confidence and trust in customer (Izogo \& Ogba, 2015).

\subsubsection{Empathy}

Empathy is about customer care by giving attention to each and every desire problem (Izogo \& Ogba, 2015) and lesioning to the problems properly and effectively addressing the needs and concerns and finally solving it.

\subsubsection{Customer Satisfaction}

According to Arsanam and Yousapronpaiboon (2014) literature is evident that the key to long-term business success is CS. Organizations must offer quality based products and services to outperform its competitors to ensure and gain CS to protect, gain and sustain its market shares (Khan \& Fasih, 2014). The industry of Umrah travelling must focus and understand customers service requirements and must learn how it impacts the service delivery and customer's attitude which according to Han and Hyun (2015), is the key factor to CS which in turn leads to customer retention and loyalty (Muala, 2016). Companies can determine the actions requirement while understanding the customer's perceptions to meet and fulfil the customers' needs.

Companies in industries like Umrah service agents must study and identify their strengths and weaknesses and compare themselves with their competitors at present and suggest strategies for improvements and progress in future (Saghier \& Nathan, 2013). The key element towards CS achievement is the products or services provider relationship with their customers specifically in the industry of Umrah travelling. Hence the offering of quality-based services and products are the key elements in retaining and satisfying valued customers (Kant \& Jaiswal, 2017). According to Maula (2016) the offering and delivery of qualitative services to customers give the firms an opportunity to compare and differentiate themselves in highly competitive markets (Muala, 2016).

\subsubsection{Service Quality and Customer Satisfaction}

In the industry of Umrah traveling, one of the most important aspects and factors in CS premium customer experience is SQ. Most of the organizations regularly check and monitor their SQ to ensure the maximum CS and to retain and maintain their pool of customers and enhance their loyalty towards their products and services in a positive way. According to Omar et al. (2015) organizations monitor customer 
desires, demands and expectations and then accordingly provide the services and products to the customers on market standards to bring and enhance CS. The feeling of customers about the products or services is totally based on consumption and usability experience of the customer. However, with CS it is not mandatory that a repurchase will occur, the same is the case with loyalty and customers' retention. Several organizational researchers consider SQ as one of a major and strong predictor in CS and costumers retention. While according to Namukasa (2013), SQ is the main driver in the CS which has an impacts on customer loyalty. SQ is an impact factor in bringing and enhancing CS. Muala (2016) argues that for Umrah travel agents it is necessary and important tool for augmenting their market share and income. From the previous discussion, the five hypotheses are proposed as follows:

1) The relationship between tangibles and Umrah customer satisfaction

Jabnoun and Hassan (2003) found that banks with better ambience enhance customer satisfaction in a better way. Association between service quality and customer satisfaction in banking sector of Sweden is examined by Zineldin (2005). A study found that by combining tangible and intangible attributes of premium quality in products and services provided by travel services, it is possible to create a strong and long-term relationship with customers.

This service quality dimension comprises of travel services, service equipment, human resources (staff) and the means of communication. In simple words tangibles are about creating foremost impressions. All organizations desire that their consumers get an exceptional and positive foremost impression. Focusing on this particular dimension will help them gain maximum benefit (Swar et al., 2012).

Rajaratnam et al. (2014) concisely explain the idea of tangibles role in travel sector. Service quality is the key tool to achieve customer's attention. Varying behaviours and attitudes of customers demand high service quality to attain their perception of service. Service quality has linear relationship with success and profitability of business.

Environment and culture of different areas serve as a guide for businesses on how to adapt their policies in global perspective for a particular area. They have to make changes to setup the outlets and branches. travel industry mostly follows identical office ambience setups and installs similar service equipment all over the globe to maintain a standard (Rajaratnam et al. 2014). But adapting according to cultural needs of particular areas up to some extent will make customers feel more comfortable and loyal (Ganguli \& Roy, 2011). The above literature reviews will lead to the development of the following hypotheses:

$\mathrm{H}_{1}$ : There is a significant relationship between tangible and Umrah customer satisfaction.

2) The relationship between reliability and Umrah customer satisfaction

The association between dimensions of service quality and customer satisfaction was investigated by Ibáñez et al. (2006). They found a significant relationship between reliability of services on the satisfaction level of customers. The literature reveals an increased degree of positive relationship between service quality, customer satisfaction and performance (both financial and non-financial) where face-to-face conversation between customer and employee is the only focus. Technology expansion has had a great impact on the choice of service delivery standard and services marketing strategies. This has yielded many prospective competitive advantages including augmenting of productivity and enhanced revenue creation from new services (Muyeed, 2012). Reliability depends on handling customer service issues, performs the services right the first time; offers services on time, and maintain a record of error-free. Moreover, they define reliability as the most significant factor in conventional service (Parasuraman et al., 1988). Reliability also consists of the right order fulfilment; accurate records; accurate quote; right in the bill; keep the promises on services. It is also mentioned that reliability is the most significant factor in travel 
services (Muala, 2016), more specifically, in a study by Parasuraman et al. (1985). The above literature reviews will lead to the development of the following hypotheses:

$\mathrm{H}_{2}$ : There is a significant relationship between reliability and Umrah customer satisfaction.

3) The relationship between responsiveness and Umrah customer satisfaction

Responsiveness is defined as "the willingness to help customers and provide prompt service" (Parasuraman et al., 1988). Furthermore, Johnston (1997) defines responsiveness such as speed and timeliness of service delivery. This consists of processing speed and service capabilities to respond promptly to customer service requests, and wait a short and queuing time. Zeithaml et al. (1996) defined responsiveness as the interests shown in providing prompt service to customers when required. Further, it is researched that willingness or readiness of employees to provide the required customer service without any inconvenience at any time will strongly influence the level of customer satisfaction (Parasuraman et al., 1988). Customers get satisfied when banks provide individual attention and the employees are paying attention to problems experienced by customers regarding safety in transaction (Ngo \& Nguyen, 2016). More specifically, responsiveness is defined as the willingness or readiness of employees to provide services. It contains the timeliness of service (Parasuraman et al., 1985). It also contains understanding the needs and requirements of the customer, easy operation time, individual attention provided by the staff, attention to the problem and customers' safety in their dealings (Ngo \& Nguyen, 2016). Finally, in this research, responsiveness is the readiness for travel services (Ashdaq et al., 2015). The above literature reviews will lead to the development of the following hypotheses:

$\mathrm{H}_{3}$ : There is a significant relationship between responsiveness and Umrah customer satisfaction.

4) The relationship between assurance and Umrah customer satisfaction

In addition to tangibles, reliability and responsiveness; assurance has been identified as a significant dimension of service quality by Parasuraman et al. (1988). They proposed that all of these dimensions significantly enhance customer satisfaction. It is believed that if the employees of travel services display trustworthy behaviour, the satisfaction level of customers can be enhanced significantly (Ashdaq et al., 2015). It may also positively influence repurchase intension of customers (Ndubisi, 2006; Ndubisi \& Wah, 2005). The above literature reviews will lead to the development of the following hypotheses:

$\mathrm{H}_{4}$ : There is a significant relationship between assurance and Umrah customer satisfaction.

5) The relationship between empathy and Umrah customer satisfaction

A positive and significant relationship is found between empathy and customer satisfaction by Iglesias and Guillén (2004). It was proposed in another research study, that customers may remain unsatisfied with service quality if a gap is left in empathy. It was also established by Al-Marri et al. (2007) that customer satisfaction is significantly impacted by empathy. It makes customers contended and in the long-run serves as an important predictor in improving the financial performance of the organization. Wieseke et al. (2012) empirically investigated the role of empathy in service quality and its impact on customer satisfaction. It was established that customers treated emphatically are more often visitors and prone forgive any mistakes that may occur. Empathy creates an emotional relationship with customer, providing customer a touch of importance for business. This leads to retention and creation of new customer's pool. Rajaratnam et al. (2014) has also studied the correlation between service quality dimensions and customer satisfaction in travel industry. It was found that customer loyalty can be won through empathy. Empathy can play role in improvement of service quality, customer loyalty and finally satisfaction. Karatepe (2011) explored the service environment impact with empathy and reliability on loyalty. Empathy works as a moderator between quality and customer satisfaction. Empathy can change the behavior of customer ultimately. The above literature reviews will lead to the development of the following hypotheses:

$\mathrm{H}_{5}$ : There is a significant relationship between empathy and Umrah customer satisfaction. 


\subsection{Research Framework}

Fig. 1 shows details of the proposed study of this paper.

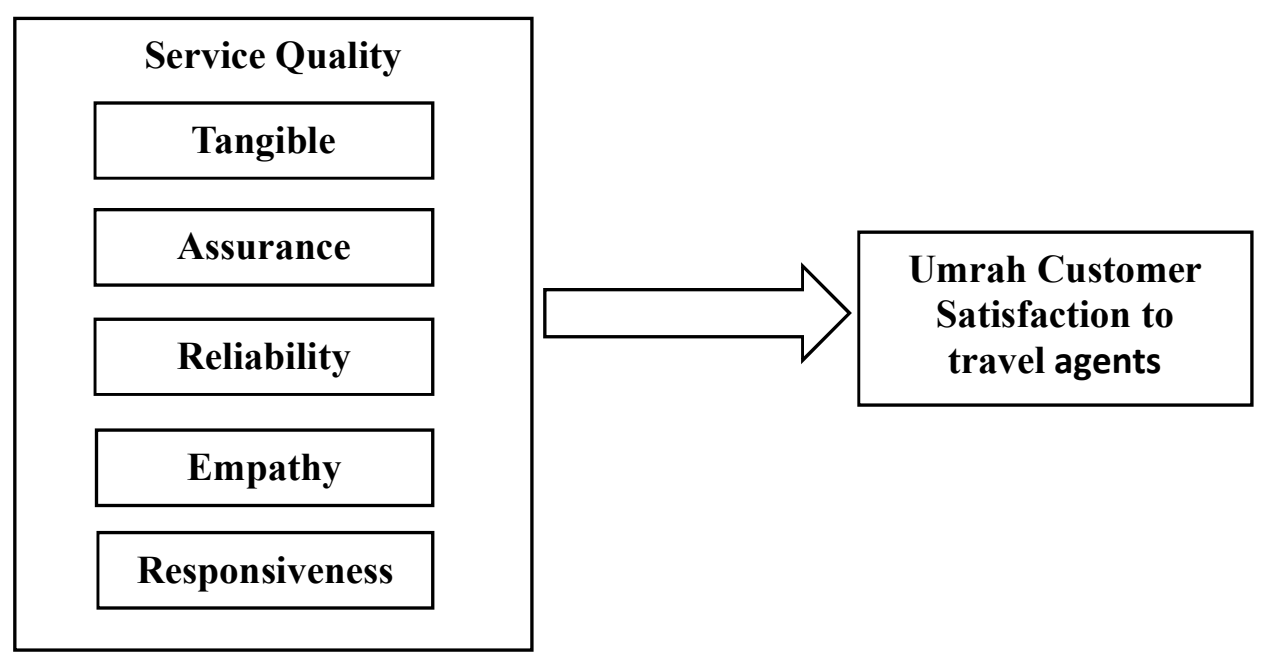

Fig. 1. The proposed study

\subsection{Research Hypotheses}

$\mathrm{H}_{1}$ : An excellent service quality provided by Umrah travel agents will lead to Umrah customer satisfaction.

$\mathrm{H}_{11}$ : An excellent tangibles provided by Umrah travel agents will lead to Umrah customer satisfaction.

$\mathrm{H}_{12}$ : Reliable services provided by Umrah travel agents will lead to Umrah customer satisfaction.

$\mathrm{H}_{13}$ : Responsiveness actions provided by Umrah travel agents will lead to Umrah customer satisfaction.

$\mathrm{H}_{14}$ : Excellent assurance provided by Umrah travel agents will lead to Umrah customer satisfaction.

$\mathrm{H}_{15}$ : Empathy provided by Umrah travel agents will lead to Umrah Customer satisfaction.

\section{Research Methodology}

This part discusses how the research is conducted and tells us about population, sample size, research design, reliability of the questionnaire and finally analysis method of the data. All Malaysian people who performed the Umrah more than once in their lives consist the population size for the research. In this survey, 500 questionnaires were distributed and 384 of the responded questionnaires were considered valid and fit for the study and they were used in the analysis portion of this paper. Sekaran (2003) believes that data from 200 and more responses are enough for a research analysis. The valid questionnaires were at $77 \%$ response rate and the questionnaire was set on 5 points Likert scale which was $(1=$ strongly disagree, $2=$ disagree, $3=$ undecided, $4=$ agree, $5=$ strongly agree). The questionnaire consists of three portions (1) demographic variables and it contains (18) items; (2) service quality and its dimensions contains (27) items which were adapted from (Parasuraman et al., 1994); while (3) CS contains (6) items which were adopted from Eisingerich et al. (2014). For comprehensive sampling, convenience sampling procedure was followed and used, it is a common form and mostly used of sampling design in social science research. To perform the analysis of the data, structural equations modelling SEM was used which depends on the partial least squares approach "PLS" to test the search model. 


\section{Results}

\subsection{Reliability Test}

We have calculated the reliability of the questionnaire and the reliability for all variables lied in the acceptable range according to Nunnally's (1978) minimum threshold of 0.70 . Table 1 shows us the Cronbach's Alpha (coefficient alpha) of each factor which shows that all the factors show a high and acceptable reliability. This table shows that in the questionnaires SQ had five independent factors and one dependent factor of CS that the researcher examined.

Table 1

Reliability results

\begin{tabular}{|c|c|c|c|c|c|}
\hline Variables & Item & Loading & Cronbach Alpha & Composite Reliability & Average Variance Extracted (AVE) \\
\hline Service Quality & SQ & 0.978 & 0.979 & 0.979 & 0.647 \\
\hline \multirow{5}{*}{ Assurance } & ASS1 & 0.863 & \multirow{5}{*}{0.943} & \multirow{5}{*}{0.957} & \multirow{5}{*}{0.815} \\
\hline & ASS2 & 0.914 & & & \\
\hline & ASS3 & 0.928 & & & \\
\hline & ASS4 & 0.931 & & & \\
\hline & ASS5 & 0.875 & & & \\
\hline \multirow{4}{*}{ Empathy } & EMP1 & 0.850 & \multirow{4}{*}{0.904} & \multirow{4}{*}{0.933} & \multirow{4}{*}{0.776} \\
\hline & EMP2 & 0.896 & & & \\
\hline & EMP3 & 0.889 & & & \\
\hline & EMP4 & 0.888 & & & \\
\hline \multirow{6}{*}{ Responsiveness } & RES1 & 0.864 & \multirow{6}{*}{0.941} & \multirow{6}{*}{0.953} & \multirow{6}{*}{0.771} \\
\hline & RES2 & 0.846 & & & \\
\hline & RES3 & 0.899 & & & \\
\hline & RES4 & 0.894 & & & \\
\hline & RES5 & 0.900 & & & \\
\hline & RES6 & 0.866 & & & \\
\hline \multirow{5}{*}{ Reliability } & REL1 & 0.883 & \multirow{5}{*}{0.933} & \multirow{5}{*}{0.949} & \multirow{5}{*}{0.788} \\
\hline & REL2 & 0.899 & & & \\
\hline & REL3 & 0.866 & & & \\
\hline & REL4 & 0.908 & & & \\
\hline & REL5 & 0.883 & & & \\
\hline \multirow{6}{*}{ Tangibles } & TAN1 & 0.758 & \multirow{6}{*}{0.920} & \multirow{6}{*}{0.938} & \multirow{6}{*}{0.715} \\
\hline & TAN2 & 0.858 & & & \\
\hline & TAN3 & 0.868 & & & \\
\hline & TAN4 & 0.850 & & & \\
\hline & TAN5 & 0.860 & & & \\
\hline & TAN6 & 0.874 & & & \\
\hline \multirow{5}{*}{$\begin{array}{c}\text { Customer Satisfac- } \\
\text { tion }\end{array}$} & CS1 & 0.909 & \multirow{5}{*}{0.931} & \multirow{5}{*}{0.951} & \multirow{5}{*}{0.795} \\
\hline & $\mathrm{CS} 2$ & 0.906 & & & \\
\hline & CS3 & 0.896 & & & \\
\hline & CS5 & 0.874 & & & \\
\hline & CS6 & 0.871 & & & \\
\hline
\end{tabular}

\subsection{Demographic Variables}

The results show that among all the respondents, $57.3 \%$ were male while only $42.7 \%$ were female. In the age portion, $26.3 \%$ of the respondents aged between 31 years to 40 years of age. $35.4 \%$ of the respondents possessed a bachelor's degree while $23.7 \%$ had a diploma. Moreover, among the total respondents $21.6 \%$ earned salaries less than 2000 RM while $22.1 \%$ earned in between 2001-3000 RM

\subsection{Hypothesis Test}

In the support of Hypothesis (1) the results of data analysis show that SQ positively and significantly affects $\mathrm{CS}$ of the total sample $(\mathrm{Beta}=0.302, \mathrm{p}=.000)$. The results of the data also show that the assurance dimension positively and significantly affect the CS of the total sample (Beta $=0.069, \mathrm{p}=.000)$. Therefore, the evidences are enough to support all Hypotheses of the study. Therefor it is concluded that SQ and its dimensions affect the CS significantly and positively. 
Table 2

Hypothesis results

\begin{tabular}{|c|c|c|c|c|c|}
\hline Path & Original Sample $(\mathrm{O})$ & Sample Mean (M) & $\begin{array}{c}\text { Standard Deviation } \\
\text { (STDEV) }\end{array}$ & $\begin{array}{l}\text { T Statistics } \\
(|\mathrm{O} / \mathrm{STDEV}|)\end{array}$ & P Values \\
\hline $\mathrm{SQ} \rightarrow \mathrm{CS}$ & 0.302 & 0.306 & 0.076 & 3.983 & 0.000 \\
\hline $\mathrm{ASS} \rightarrow \mathrm{CS}$ & 0.069 & 0.070 & 0.017 & 4.007 & 0.000 \\
\hline $\mathrm{EMP} \rightarrow \mathrm{CS}$ & 0.048 & 0.048 & 0.012 & 3.882 & 0.000 \\
\hline $\mathrm{RES} \rightarrow \mathrm{CS}$ & 0.077 & 0.079 & 0.020 & 3.945 & 0.000 \\
\hline $\mathrm{REL} \rightarrow \mathrm{CS}$ & 0.065 & 0.066 & 0.016 & 3.954 & 0.000 \\
\hline $\mathrm{TAN} \rightarrow \mathrm{CS}$ & 0.070 & 0.071 & 0.017 & 4.033 & 0.000 \\
\hline
\end{tabular}

\section{Conclusions}

In this research paper the researchers have tried to examine the effect of Umrah travelling SQ dimensions (Tangibility, Reliability, Empathy, Responsiveness, Assurance) on CS in Malaysia. The study has accomplished using the partial least squares approach "PLS" and the results of the path analysis show us that all the dimensions of SQ effect CS. Among all the independent variables, tangible among the dimension of SQ shows the highest effect on CS. On the basis of these results, the researchers have concluded and recommended that Umrah travel agent should consider improving the responsiveness and the assurance dimensions of the SQ in order to satisfy their customers and to enhance their buying decision and behaviour of the Umrah travel service.

\section{Limitations and Future Research}

The first and most important limitation of this research paper is that the sample was taken from few parts of Malaysia, only from some states, namely Johor, Selangor, Sabah, Penang states, which effects the generalizability of the findings of the research paper. Secondly, foreign Umrah user were not considered and studied in this research. In future, researchers must examine a wider and diverse range of sample covering Umrah customers from all walks and portions of life. Thirdly, this study only considered the impact of one factor (service quality) SQ on CS in the industry of Umrah travel agents.

There can also be other situational issues and factors such as price, repurchase intention advertising, and word-of-mouth recommendation. In future empirical studies, researches should focus and look at the impact of factors like these on CS. Finally, the findings of our research paper were based on the results which came from the analysis of responses which were selected through convenience sampling, hence our study should be considered starting point and pilot study which will help in providing direction for future research and also for its generalization to the considering of wider portion of the population of the Umrah travel industry in future.

\section{References}

Al-Marri, K. S., Abdel Moneim, M., Baheeg, A., \& Zairi, M. (2007). Excellence in services: An empirical study in the UAE banking sector. International Journal of Quality Reliability Management, 24(2), 164-76.

Arsanam, P., \& Yousapronpaiboon, K. (2014). The relationship between service quality and customer satisfaction of pharmacy departments in public hospitals. International Journal of Innovation, Management and Technology, 5(4), 261.

Ashdaq, M., Maupa, H., Amar, M. Y., \& Nursyamsi, I. (2015). Analysis of service quality on pilgrims satisfaction and image of hajj and umrahs travel agents In south sulawesi province, Indonesia. International Journal of Research In Social Sciences, 5(6).

Eisingerich, A. B., Auh, S., \& Merlo, O. (2014). Acta non verba? The role of customer participation and word of mouth in the relationship between service firms' customer satisfaction and sales performance. Journal of Service Research, 17(1), 40-53.

Izogo, E. E., \& Ogba, I. E. (2015). Service quality, customer satisfaction and loyalty in automobile repair services sector. International Journal of Quality \& Reliability Management, 32(3), 250-269. 
Ganguli, S., \& Roy, S. K. (2011). Generic technology-based service quality dimensions in banking: Impact on customer satisfaction and loyalty. International journal of bank marketing, 29(2), 168-189.

Han, H., \& Hyun, S. S. (2015). Customer retention in the medical tourism industry: Impact of quality, satisfaction, trust, and price reasonableness. Tourism Management, 46, 20-29.

Hassan, S. H., Maghsoudi, A., \& Nasir, N. I. M. (2016). A conceptual model of perceived value and consumer satisfaction: a survey of Muslim travellers' loyalty on Umrah tour packages. International Journal of Islamic Marketing and Branding, 1(3), 215-237.

Ibáñez, V. A., Hartmann, P., \& Calvo, P. Z. (2006). Antecedents of customer loyalty in residential energy markets: Service quality, satisfaction, trust and switching costs. The Service Industries Journal, 26(6), 633-650.

Jabnoun, N., \& Hassan Al-Tamimi, H. A. (2003). Measuring perceived service quality at UAE commercial banks. International Journal of Quality \& Reliability Management, 20(4), 458-472.

Jain, S. K., \& Gupta, G. (2004). Measuring service quality: SERVQUAL vs. SERVPERF scales. Vikalpa, 29(2), 25-38.

Johnston, R. (1997). Identifying the critical determinants of service quality in retail banking: importance and effect. International Journal of bank marketing, 15(4), 111-116.

Kant, R., \& Jaiswal, D. (2017). The impact of perceived service quality dimensions on customer satisfaction: an empirical study on public sector banks in India. International Journal of Bank Marketing, 35(3), 411-430.

Karatepe, O. M. (2011). Service quality, customer satisfaction and loyalty: the moderating role of gender. Journal of Business Economics and Management, 12(2), 278-300.

Khan, M. M., \& Fasih, M. (2014). Impact of service quality on customer satisfaction and customer loyalty: Evidence from banking sector. Pakistan Journal of Commerce and Social Sciences (PJCSS), 8(2), 331-354.

Kumar, A. (2017). Effect of service quality on customer loyalty and the mediating role of customer satisfaction: an empirical investigation for the telecom service industry. Journal of Management Research and Analysis, 4(4), 159-166.

Mahfooz, Y. (2014). Relationship between service quality and customer satisfaction in hypermarkets of Saudi Arabia. International Journal of Marketing Studies, 6(4), 10.

Muala, A. A. (2016). The effect of service quality dimensions on customers' loyalty through customer satisfaction in Jordanian Islamic Bank. International Journal of Marketing Studies, 8(6), 141-146.

Muhammad Awan, H., Shahzad Bukhari, K., \& Iqbal, A. (2011). Service quality and customer satisfaction in the banking sector: A comparative study of conventional and Islamic banks in Pakistan. Journal of Islamic Marketing, 2(3), 203-224.

Muyeed, M. A. (2012). Customer perception on service quality in retail banking in developing countriesa case study. International Journal of Marketing Studies, 4(1), 116.

Namukasa, J. (2013). The influence of airline service quality on passenger satisfaction and loyalty: The case of Uganda airline industry. The TQM Journal, 25(5), 520-532.

Ngo, M. V., \& Nguyen, H. H. (2016). The relationship between service quality, customer satisfaction and customer loyalty: An investigation in Getnamese RetaiVil Bankin Sector. Journal of Competitiveness, 8(2), 103-16.

Nunnally, J. C., Bernstein, I. H., \& Berge, J. M. T. (1967). Psychometric theory (Vol. 226). New York: McGraw-hill.

Omar, H. F. H., Saadan, K. B., \& Seman, K. B. (2015). Determining the influence of the reliability of service quality on customer satisfaction: The case of Libyan E-commerce customers. International Journal of Learning and Development, 5(1), 86-89.

Othman, B., Harun, A., Rashid, W., Nazeer, S., Kassim, A., \& Kadhim, K. (2019). The influences of service marketing mix on customer loyalty towards Umrah travel agents: Evidence from Malaysia. Management Science Letters, 9(6), 865-876.

Othman, B. A., Harun, A. B., \& Nazeer, S. (2018). Issues and Challenges Faced by Malaysian Umrah Travel Agencies in Providing Excellent Marketing Mix Services to Umrah Pilgrims. The Journal of Social Sciences Research, 611-618. 
Parasuraman, A., Berry, L., \& Zeithaml, V. (2002). Refinement and reassessment of the SERVQUAL scale. Journal of retailing, 67(4), 114.

Parasuraman, A., Zeithaml, V. A., \& Berry, L. L. (1988). Servqual: A multiple-item scale for measuring consumer perc. Journal of retailing, 64(1), 12.

Parasuraman, A., Zeithaml, V. A., \& Berry, L. L. (1994). Reassessment of expectations as a comparison standard in measuring service quality: implications for further research. Journal of marketing, 58(1), 111-124.

Pedraja Iglesias, M., \& Jesus Yagüe Guillén, M. (2004). Perceived quality and price: their impact on the satisfaction of restaurant customers. International Journal of Contemporary Hospitality Management, 16(6), 373-379.

Thongthip, W., \& Polyorat, K. (2015). The influence of brand personality dimensions on perceived service quality and perceived service value. The Business \& Management Review, 6(4), 22.

Rajaratnam, S. D., Munikrishnan, U. T., Sharif, S. P., \& Nair, V. (2014). Service quality and previous experience as a moderator in determining tourists' satisfaction with rural tourism destinations in Malaysia: A partial least squares approach. Procedia-Social and Behavioral Sciences, 144, 203-211.

El Saghier, N., \& Nathan, D. (2013, April). Service quality dimensions and customers' satisfactions of banks in Egypt. In Proceedings of 20th International Business Research Conference (Vol. 13).

Swar, B.N., Sahoo, \& Kumar, P. (2012). Service quality: Public, private, and foreign banks. SCMS Journal of Indian Management, 9(3), 43.

Vanniarajan, T., \& Gurunathan, P. (2009). Evaluation of linkage between service quality, customer satisfaction and repurchase intentions: An application of SEM. Asia Pacific Business Review, 5(4), 108118.

Wieseke, J., Geigenmüller, A., \& Kraus, F. (2012). On the role of empathy in customer-employee interactions. Journal of Service Research, 15(3), 316-331.

Zeithaml, V. A., Berry, L. L., \& Parasuraman, A. (1996). The behavioral consequences of service quality. Journal of marketing, 60(2), 31-46.

Zineldin, M. (2005). Quality and customer relationship management (CRM) as competitive strategy in the Swedish banking industry. The TQM magazine, 17(4), 329-344.

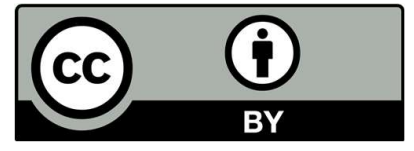

(C) 2019 by the authors; licensee Growing Science, Canada. This is an open access article distributed under the terms and conditions of the Creative Commons Attribution (CCBY) license (http://creativecommons.org/licenses/by/4.0/). 